\title{
Phycoremediation of Heavy Metal Removal from Pharmaceutical Industrial Effluents, Kandigai, Kanchipuram District, Tamil Nadu
}

\author{
Prathiba S. ${ }^{1}$, Muninathan N. ${ }^{2}$, Ponnulakshmi R. ${ }^{2}$, Nalini D. ${ }^{2}$ \\ ${ }^{1}$ Lecturer, Department of Pharmacology, Meenakshi Ammal Dental College and Hospital, Chennai, India, \\ ${ }^{2}$ Research Scientist, Central Research Laboratory, Meenakshi Medical College Hospital and Research Institute, \\ Enathur, Kanchipuram, Tamilnadu, India
}

\begin{abstract}
Water pollution occurs due to excessive releases of toxic heavy metals in urban wastewater is increasing the threat to aquatic ecosystems. Treatment of waste water with the algae is termed as Phycoremediation which is a unique, cheap, method to treat the polluted water by a method of natural selection. Therefore, in the present study effluents with an algal species were taken for Phycoremediation using five different concentrations were used for treating pharmaceutical industrial effluents. Our research focused on microalgae Chlorella sp. and Scenedesmus sp. were used to treat the effluent at different concentrations depending upon the tolerance in severe conditions. In addition to this treatment algal consortium was also treated in the same way. These two algal species were taken based on its predominant growth in the effluents collected. The physico-chemical parameters of all treated effluents were recorded in different time intervals, from $1^{\text {st }}$ week to $3^{\text {rd }}$ week respectively. Chlorella and Scenedesmus sp. reduces drastically heavy metals like sulfate, lead, nickel, copper and zinc. According to the present investigation, the highest Phycoremediation was achieved in sulfate, zinc and copper. The results revealed that the above mentioned both algal species were also highly efficient in reducing BOD, COD, TSS and TDS. In addition to this the biochemical and bio pigment analyses were done for these two micro algal species. Therefore, this preliminary study indicates that the use of two microalgal sp. could be used as they are eco-friendly adsorbents in treatment of polluted wastewater.
\end{abstract}

Keywords: Consortia, Chlorella sp., Phycoremediation, Scenedesmus sp.

\section{Introduction}

Heavy metals are exposed chemicals present in waste water, which has higher density than water. Depending upon heaviness, the toxicity caused by these heavy metals is of serious health concern. The metalloids like lead, arsenic zinc when present in least amount doesn't produce toxicity, but when formulating industries releases tones of heavy metals the ground water gets totally disturbed and the outcome of this is diseases due to contamination. Thus, public health and

\footnotetext{
Corresponding Author:

Prathiba S.

Lecturer, Department of Pharmacology, Meenakshi

Ammal Dental College and Hospital, Chennai, India

e-mail: prathibamahesh86@gmail.com
}

ecological disturbances affects the population and the environment by these toxic heavy metals.

The major concern causing heavy metal contamination is due to the increased population which acts as a cycle so more demands rises and more people are employed in industrial, domestic and commercial sectors. The toxicity produced by these sectors when directly released into the nearby ponds and pools the health hazard is a common criterion in these exposed areas. The industries which produce heavy toxic metals are mining industry, smelting industry or any metal manufacturing industries, though the metals are required in the body to some extent but larger proportions leads to severe illness. Wastewater with these heavy metals is a serious threat to the environment because of the presence of poisonous nature ${ }^{[6,9]}$. The heavy metals released from the pharmaceutical industry contain mutagenic and carcinogenic agents ${ }^{[4]}$. 
To overcome this issue a new technology of Bioremediation was in practice to transform harmful organisms by inhibiting its growth and making the effluent to be good to deliver in the ponds or estuaries. This alga based technology treats the wastewater and absorbs the heavy metals and make the water fit for drinking. Hence this treatment plan was economically feasible and eco-friendly in nature ${ }^{[13]}$. The nutrient rich wastewater reduces pollutants and helps to maintain the external conditions ${ }^{[7,11]}$.

Thus, our research focus on treating the heavy metal contaminated pharmaceutical waste water using micro algae is more efficiently uses the heavy metals to take up the nutrients and produces a valuable biomass to produce other byproducts ${ }^{[10-12]}($ Park, 2011; Venkata Mohan, 2011, 2015, 2016a). The phycoremediation is very cheap and low growth period to remove heavy toxic metals and possess other applications.

\section{Materials and Method}

Sample collection: The wastewater sample was collected from the Pharmaceutical Industry, Kandigai, Kanchipuram district, Tamil Nadu. Algal deposits were collected from the sites and physiochemical parameters were recorded using an YSI Multi parameter.

Identification of algae: The collected algal samples were observed in the microscope and based on the structural morphology and by the expert handling the algae was identified. The selected 2 algal strains were Chlorella sp. and Scenedesmus sp. These two algae were collected by serial dilution method and spread plate method. The purified culture was grown in Bold Basal Medium and culture was maintained for 21 days to obtain the growth curve.

Analysis of Growth curve: The growth rate of the experiment was kept in optimal conditions of 12:12 (Light: Dark) at a temperature of $28^{\circ} \mathrm{C}$. The periodic monitoring of the sample was measured and shows a peak at $680 \mathrm{~nm}$. Three samples (Chlorella sp., Scenedesmus sp. and consortium) were frequently checked to establish a growth curve for a period of 21 days for 5 different concentration and control samples.

Physiochemical and Biochemical tests: The physiochemical parameter is checked for both untreated and treated effluent by using microalgae was estimated (APHA, AWWA, and WEF. 1998). The pigments such as Chlorophyll $\mathrm{a}, \mathrm{b}$ and $\mathrm{a}$-carotene were estimated by the following method; ${ }^{[5]}$ Jeffrey and Humphrey method, 1975 and ${ }^{[8]}$ MacKinney method, 1941 respectively using different wavelengths by a UV visible spectrophotometer (Hitachi U-2900). Bio-Chemical analysis, such as Carbohydrate (Dubois et al. method 1956) ${ }^{[2]}$, Protein [1] and Lipid [3] were also determined. The absorption of metals by algae was studied using Scanning Electron Microscopy (Golab, 1992).

\section{Results}

Physiochemical parameters: The various physico-chemical parameters measured were $\mathrm{pH}$, water temperature, dissolved oxygen, BOD and COD. The water temperature in pharmaceutical industry ranges from 28.0 to $32.0^{\circ} \mathrm{C}$. The $\mathrm{pH}$ of sampling site ranged between 5.8- 6.7. The value of the dissolved oxygen content of water is 4.1 to $9.52 \mathrm{mg} / \mathrm{L}$. Pharmaceutical industry waste water sample shows COD $(1240 \mathrm{mg} / \mathrm{L})$ and BOD was observed as $(374 \mathrm{mg} / \mathrm{L})$ in the sampling site. Based on the quick adaptation and the high growth rate the microalgae strains were selected. The growth rate was calculated using spectrophotometric readings for 21 days.

Biochemical parameters: The Chlorella sp., Scenedesmus sp. and consortium showed the extracted sample was subjected to biomass productivity till 21 days of incubation. The estimation of protein content was high in Scenedesmus sp. (45.10\%) consortium (39\%) and least in Chlorella sp. (18.65\%). The carbohydrate and lipid show a high amount in a consortium of $17.12 \mu \mathrm{g} /$ $\mathrm{ml}^{-1}$ and $40.49 \%$ and both Chlorella and Scenedesmus sp., shows a similar range of 15.07 and $15.67 \mu \mathrm{g} / \mathrm{ml}^{-1}$ and $38.10 \%$ and $18.89 \%$.

Table 1: Biochemical Composition of Selected micro algal species

\begin{tabular}{|l|c|c|c|}
\hline Sample & Protein (\% dwt) & Carbohydrate (\% dwt) & Lipid (\% dwt) \\
\hline Chlorella Sp. & 18.65 & 15.07 & 38.1 \\
\hline Scenedesmus Sp. & 45.1 & 15.67 & 18.89 \\
\hline Consortium & 39 & 17.12 & 40.49 \\
\hline
\end{tabular}




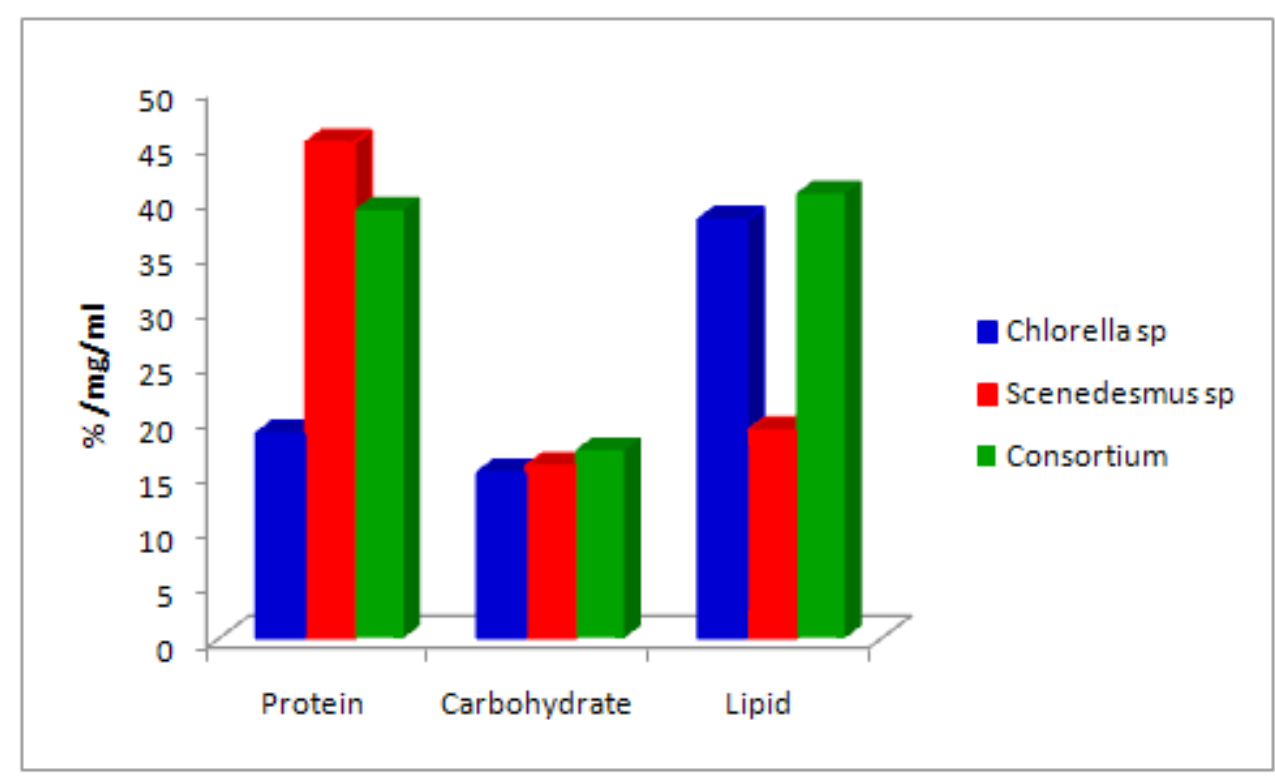

\section{Graph 1: Biochemical parameters of microalgal strains}

Pigment Analysis: The chlorophyll and carotenoid pigments were tested for efficacy of selected microalgal strains of which consortium $18.12 \mu \mathrm{g} \mathrm{ml}^{-1}$ and 192.15 $\mathrm{mg} \mathrm{m} \mathrm{ml}^{-1}$ showed high range compared with the individual species of Chlorella sp. and Scenedesmus sp $15.343 \mu \mathrm{g} \mathrm{ml}^{-1}, 185.23 \mathrm{mg} \mathrm{ml}^{-1}$ and $11.16 \mu \mathrm{g} \mathrm{ml}^{-1}$ and $145.8 \mathrm{mg} \mathrm{ml}^{-1}$.

Table 2: Quantitative analysis of Pigment from Selected micro algal species

\begin{tabular}{|c|c|c|c|}
\hline Sample & Chlorophyll a $\left(\mu \mathrm{g} \mathrm{ml}^{-1}\right)$ & Chlorophyll b $\mu \mathrm{g} \mathrm{ml}^{-1}$ ) & $\beta$-carotene $\left(\mathrm{mg} \mathrm{ml}^{-1}\right)$ \\
\hline Chlorella sp. & 15.343 & 25.134 & 185.23 \\
\hline Scenedesmus sp. & 11.76 & 16.13 & 145.8 \\
\hline Consortium & 18.12 & 23.31 & 192.15 \\
\hline
\end{tabular}

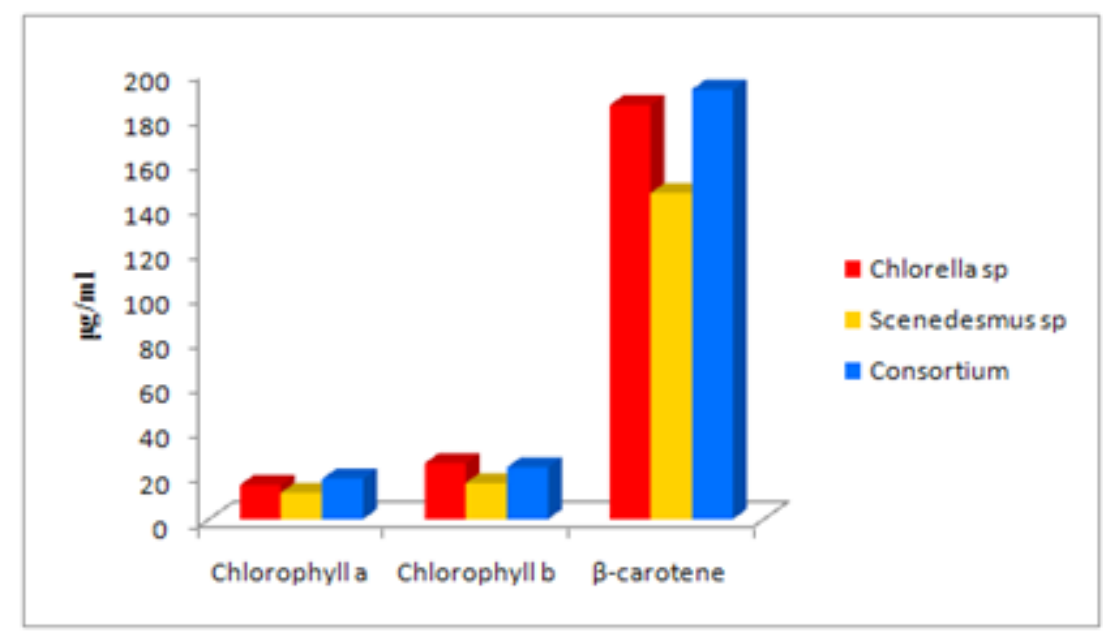

Graph 2: Pigment analysis of selected microalgal strain. 


\section{Conclusion}

The industries and pharmaceutical manufacturing companies should abide by the rules of FDA to maintain the quality of waste water and these industries should discharge and reuse without releasing the toxicity. Phycoremediation technique is a promising source to treat the waste water without causing any health hazards and also making the environment green and clean. The selected algal strains help in reducing the toxicity and facilitate 3R's. The use of wastewaters for cultivating microalgae is necessary in order to reduce the cost of microalgae production. Furthermore, countries like India with abundant sunshine are suited well for Phycoremediation as a method of green technology.

\section{Ethical Clearance: Nil}

Source of Funding: Meenakshi Academy of Higher Education and Research, Chennai, India

\section{Conflict of Interest: Nil}

\section{References}

1. Bradford MM. A rapid and sensitive method for the quantitation of microgram quantities of protein utilizing the principle of protein-dye binding. Analytical biochemistry. 1976 May 7;72(1-2):24854.

2. Dubois M, Gilles KA, Hamilton JK, Rebers PT, Smith F. Colorimetric method for determination of sugars and related substances. Analytical chemistry. 1956 Mar 1;28(3):350-6.

3. Folch J, Lees M, Stanley GS. A simple method for the isolation and purification of total lipides from animal tissues. Journal of biological chemistry. 1957 May 1;226(1):497-509.

4. Idris MA, Kolo BG, Garba ST, Ismail MA. Physicochemical analysis of pharmaceutical effluent and surface water of River Gorax in Minna, Niger State, Nigeria. Bull. Environ. Pharmacol. Life Sci. 2013 Feb 3;2(3):45-9.
5. Jeffrey ST, Humphrey GF. New spectrophotometric equations for determining chlorophylls $\mathrm{a}, \mathrm{b}, \mathrm{cl}$ and c2 in higher plants, algae and natural phytoplankton. Biochemie und physiologie der pflanzen. 1975 Jan 1;167(2):191-4.

6. Kaplan D, Abeliovich A, Ben-Yaakov S. The fate of heavy metals in wastewater stabilization ponds. Water Research. 1987 Oct 1;21(10):1189-94.

7. De-Bashan LE, Bashan Y. Immobilized microalgae for removing pollutants: review of practical aspects. Bioresource technology. 2010 Mar 1;101(6):161127.

8. Mackinney G. Absorption of light by chlorophyll solutions. J. biol. Chem. 1941 Aug 1;140(2):31522.

9. Oswald WJ, Gotaas HB. Photosynthesis in sewage treatment. Trans. Am. Soc. Civ. Eng. 1957 Jan 1;122(1):73-105.

10. Mohan SV, Devi MP, Mohana krishna G, Amarnath N, Babu ML, Sarma PN. Potential of mixed microalgae to harness biodiesel from ecological water-bodies with simultaneous treatment. Bioresource technology. 2011 Jan 1;102(2):110917.

11. Mohan SV, Nikhil GN, Chiranjeevi P, Reddy CN, Rohit MV, Kumar AN, Sarkar O. Waste biorefinery models towards sustainable circular bioeconomy: critical review and future perspectives. Bioresource technology. 2016 Sep 1;215:2-12.

12. Mohan SV, Rohit MV, Chiranjeevi P, Chandra R, Navaneeth B. Heterotrophic microalgae cultivation to synergize biodiesel production with waste remediation: progress and perspectives. Bioresource technology. 2015 May 1;184:169-78.

13. Yati P, Soni SK, Gupta S. Sonal. Potential of Algae in Bioremediation of Waste water: Current. Research, Int. J. Curr. Microbiol. App. Sci. 2016;5(2):693-700. 